\title{
Documenting livelihood trajectories in the context of development interventions in northern Burkina Faso
}

\author{
Colin Thor West ${ }^{1}$ \\ University of North Carolina, Chapel Hill, USA
}

\section{Introduction}

In Smallholders, Householders (1993) Robert McC. Netting argued that family-based intensive farming systems are ubiquitous, enduring and inherently sustainable forms of small-scale agriculture. Twenty years later, smallholders certainly persist but their future is increasingly challenged by climatic change, globalization, urbanization, and numerous other global processes. Scholars continue to draw on Netting's smallholder model and apply it in the contemporary context of global environmental change (Crate 2003; McCabe 2003; Stone 2003). Yet, assessing smallholder sustainability is problematic, which makes designing appropriate interventions difficult. Numerous development frameworks have appeared over the years that attempted to integrate household-based production systems within larger macro-economic goals. The Sustainable Livelihoods Approach (SLA) emerged in the early-1990s as an outgrowth of these efforts.

Practitioners of SLA recognized that rural producers use a broad suite of capitals in order to enhance their opportunities in the face of challenges (Bebbington 1999; Scoones 1998). Numerous large international development NGOs quickly adopted the sustainable livelihoods framework and integrated it into their missions (de Haan and Zoomers 2005; Knutsson 2006). Despite the rise of other subsequent development paradigms, SLA has left a lasting impression on the field. As Ian Scoones (2009: 181) states, "The rise of livelihood perspectives in rural development thinking and practices from the 1990s did make a difference." One of the places in which this approach to rural development has been particularly successful is the northern Central Plateau of Burkina Faso.

Evaluating the success of development projects also necessitates adding a temporal dimension to the research design. Livelihood assessments frequently lack this perspective and rarely use longitudinal or panel data. This is especially true for more rigorous qualitative and quantitative studies because this kind of data collection is expensive and time-consuming (see Davies 1996). There are exceptions such as Valdivia's (2005) study of Bolivian livestock portfolios in which her team surveyed households three times over a sixyear period. Among these few longitudinal SLA studies, most are restricted to short time-spans of three to possibly ten years. The study presented here seeks to add a greater temporal dimension to livelihoods research and utilizes data from previous surveys conducted over twenty years ago as a baseline for comparison with similar data collected in 2004. As such, it quantitatively evaluates progress toward greater sustainability across multiple asset categories of natural, financial, and human capital. Because my analysis is limited to existing datasets at only two different points in time, I use it to identify general positive or negative trends in what I call 'livelihood trajectories.' This framework was proposed and elaborated by de Haan and Zoomers (2005) to systematically compare livelihoods in different geographic, socio-economic, and temporal contexts. The analysis presented here attempts to do so with a quantitative emphasis.

Mossi communities on the northern Central Plateau have become a celebrated example of successful adaptation to climatic and social change due to their widespread adoption of Soil and Water Conservation (SWC) technologies. The positive effects of SWC interventions on crop yields, spontaneous tree regeneration, and soil conservation are well-established (Reij et al. 2005; Reij and Thiombiano 2003). The degree to which they have contributed to household livelihood sustainability, however, has not been as rigorously assessed. The study presented here on Mossi smallholders uses SLA as a framework and guide for evaluation. It measures household assets across three villages in which SWC projects have intervened. Households draw on different types of social and material capital in order to respond to shocks and overcome them. As discussed in greater detail below, livelihoods are defined as more sustainable if members are able to manage their resources in such a way that they become less sensitive and more resilient to droughts, floods, illnesses, or other shocks. It compares these recent results with those of other Mossi villages surveyed in the 1960s, 1970s, and 1980s. These earlier studies took place in villages that had few or no SWC investments at the time they were studied. Thus, their data provides a rough pre-SWC intervention control for my post-SWC data. Based on this before-after comparison, I conclude that whereas other works have documented the

\footnotetext{
${ }^{1}$ Assistant Professor, Department of Anthropology, University of North Carolina, CB \#3115, Chapel Hill, NC 27517, USA. Email: ctw "at"email.unc.edu. I would like to thank Drs. Simon Batterbury, Timothy J. Finan, Mark Moritz, Rudi Colloredo-Mansfeld and two anonymous reviewers for their assistance in improving this article. This research was supported by the Population Council Social Science Dissertation Research Fellowship, UNC Chapel Hill Explorations in Global Health Grant, the UNC Chapel Hill R.J. Reynolds Junior Faculty Development Award, and a UNC Odum Social Science Seed Grant for Multidisciplinary Research.
} 
tremendous benefits of SWC investments in terms of natural capital, I show that benefits in other forms of capital are more mixed. This is due to regional climatic trends and the recent political-economic context that shapes opportunities to diversify livelihoods.

\section{Sustainable livelihoods}

There are numerous varieties of Sustainable Livelihood Approaches that vary in terms of their methods and theoretical groundings. Some are more qualitative and draw on narratives of household struggle within a political ecology perspective (e.g., Bebbington 2001). Others combine both qualitative and quantitative data to describe the vulnerability of different agricultural sectors to inform development programming (e.g., Baro 2002). Despite these differences, studies share some core concepts and definitions. Conceptually, a livelihood;

Comprises the capabilities, assets (including both material and social resources) and activities required for a means of living. A livelihood is sustainable when it can cope with and recover from stresses and shocks, maintain or enhance its capabilities and assets, while not undermining the natural resource base... (Scoones 1998: 5)

Analytically, SLA focuses on the assets, capabilities or capitals households possess and how they mobilize them to improve their well-being and conserve local environments.

In general, livelihood systems in developing countries adapt to ecological and economic risk by diversifying (see Ellis 2000). Households "construct a diverse portfolio of activities and social support capabilities in their struggle for survival and in order to improve their standards of living" (Ellis 1998: 4). Thus, they deliberately develop income streams and social networks that permit the household to rely less heavily on agriculture. For the Kano close-settled zone in northern Nigeria, Mortimore and Adams (1999: 144-145) describe a step-wise model of diversification that begins with cropping, extends to investment in animals, followed by investment in commerce, and ends with off-farm activities. In this sense, households first seek to ensure self-sufficiency in grain production. Then, they take advantage of market opportunities to incrementally augment their livelihood sustainability through investments in livestock and trade.

Similarly, smallholders draw on these investments as they confront shocks associated with droughts, illnesses, or other events that negatively affect their livelihoods. Jane Corbett (1988) describes how rural African households sequentially cope with famine. In the initial stage, they seek to preserve assets by reducing consumption, collecting wild foods, and selling off small livestock such as goats and sheep. As the famine continues, households are forced to dispose of productive assets such as cattle, donkeys, ploughs, or carts. In the final stage, households become destitute and engage in distress migration or are reduced to begging.

These two models closely resemble contemporary Mossi livelihood systems on the northern Central Plateau of Burkina Faso described in greater detail below. Generally speaking, households prioritize maintaining adequate grain stocks to meet the consumption demands of their members. Once these needs are met, they invest labor, time and money in activities that will increase grain production by intensifying their agricultural system. Household members simultaneously invest in non-farm activities that will allow them to diversify and accumulate money, animals, or grain (see McMillan 1995). This process is self-reinforcing and results in a positive feedback loop of asset accumulation similar to that described by Mortimore and Adams (1999). When droughts occur and they face production shortfalls, the entire process of asset accumulation is short-circuited. Households sell off animals, divert money from off-farm activities, and engage in the reverse process of asset divestment in order to purchase grain. In cases of severe and prolonged droughts, Mossi households can become destitute and migrate away or simply remain in their home village and suffer (McMillan 1995; Roncoli et al. 2001). Figure 1 depicts this dual process of household asset accumulation and divestment.

In terms of operationalizing SLA, the sustainability of a livelihood system is a function of two characteristics: sensitivity and resilience. The sensitivity of a livelihood is the degree to which it is negatively impacted by external shocks such as drought. The resilience of a livelihood is the duration of time required for the system to adapt and recover from the shock. Figure 2 illustrates the relationship between sensitivity and resilience, modified from the figure Susanna Davies (Davies 1996: 27) presents in her book, Adaptable livelihoods: coping with food insecurity in the Malian Sahel. Empirical evidence from SLA case studies demonstrates households proactively and purposively seek to progressively shift their livelihood system toward greater sustainability - i.e., decreasing their sensitivity and increasing their resilience (Tiffen et al. 1994; Swift 1996). However, the structural and environmental contexts in which these livelihoods are embedded often impede the ability of households to do so. Examples from the Niger River Delta in Mali (Davies 1996) and Northwest Haiti (Baro 2002) describe how rural livelihoods are definitively becoming more sensitive and less resilient to shocks - i.e., categorically unsustainable. 


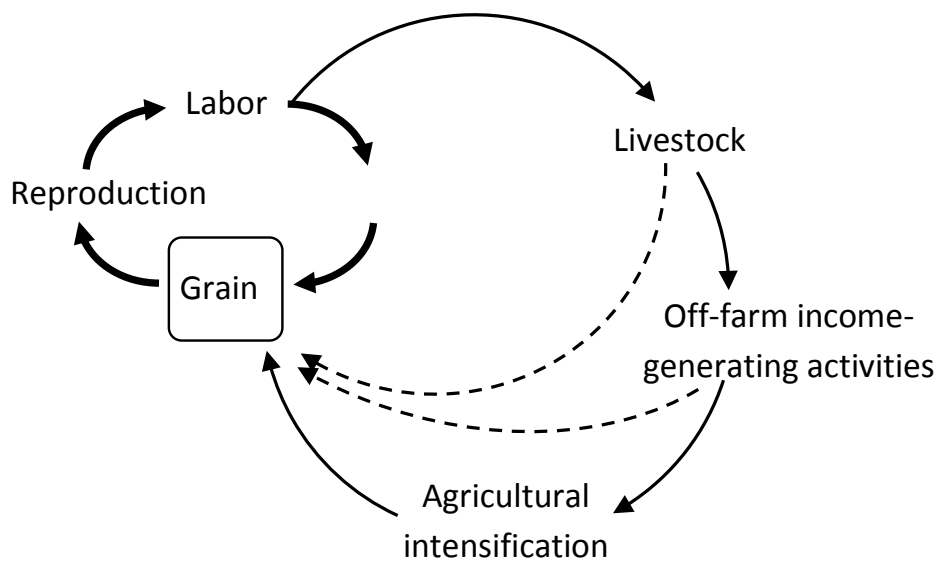

Figure 1: Model of household asset accumulation and divestment. Heavy dark lines indicate household priorities; lighter dark lines indicate positive, secondary pathways of accumulation; dotted lines indicate negative pathways of divestment.

This article assesses sustainability by comparing household livelihood assets at two different points in time. By doing so, I can detect whether assets in these categories have increased or decreased between the two periods. Ideally, assessing Mossi livelihoods would entail multiple measurements of the same households in the same community at regular points in time. Unfortunately, such long term repeat studies do not exist for Burkina Faso or the northern Central Plateau. But, it is possible to take published results from previous studies and use them as a baseline. Then, using more recent data one can compare them. Such 'livelihood trajectories' are analogous to fundamental geometry. Having two points, you can consider one as an endpoint and the other a direction. It is possible to draw a line between the two, but the line begins at the endpoint, passes through the directional point and continues at the same slope indefinitely in the same plane. This line is formally a vector and suggests only the direction of change (positive, negative, or neutral) and indicates to a much more limited sense its magnitude, slope, or angle (Figure 3). Because longitudinal and quantitative data on Mossi assets are so sparse, I argue that this study shows how such partial data can be used to indicate these vectors and at least suggest such livelihood trajectories.

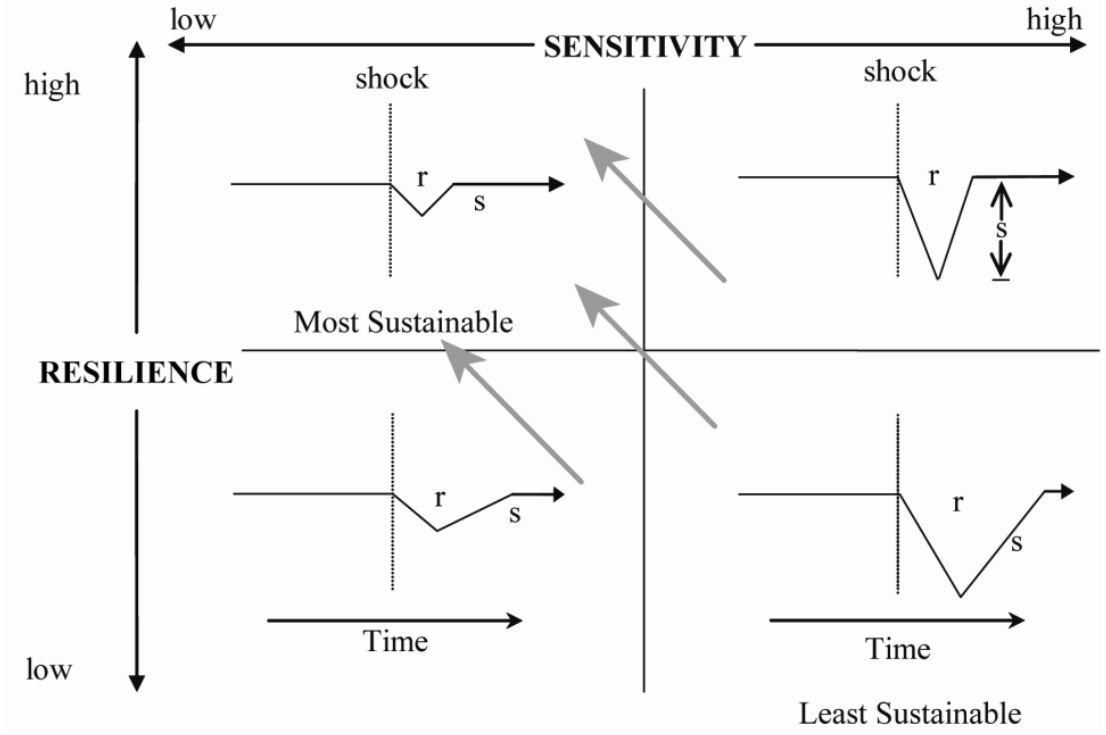

Figure 2: Conceptual diagram of sustainability, modified from Davies (1996: 27). 

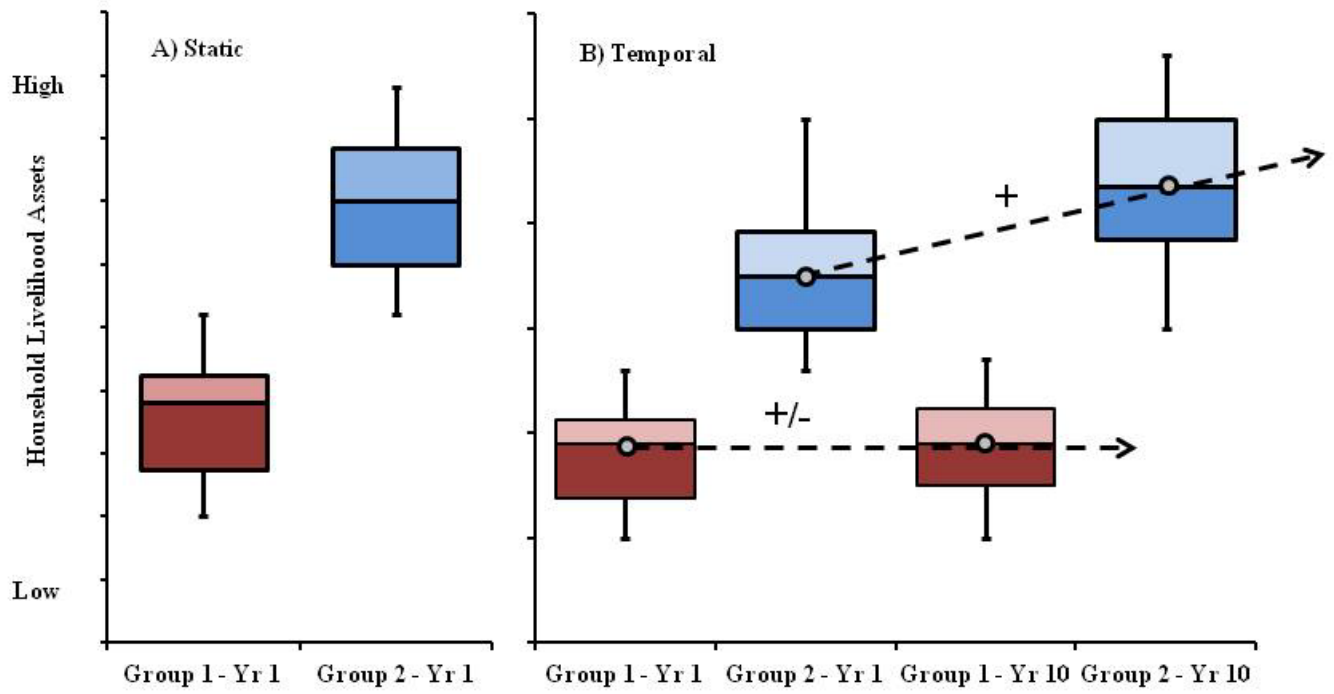

Figure 3: Livelihood assessment diagrams. Left panel (a) suggests static assets approach; right panel (b) suggests temporal approach and change in assets over time as positive or neutral trajectories.

\section{Soil and water conservation (SWC) on the northern Central Plateau}

\section{Regional desiccation}

The Central Plateau is an elevated plain encompassing nearly one-third of Burkina Faso. The northern portion is semi-arid where annual rainfall measures between 400 and $900 \mathrm{~mm}$. The rainy season begins in May or June and lasts until August or September. This woody savanna region lies within the Sudano-Sahel transition zone (Batterbury 1997). Vegetation consists primarily of thorny scrub mixed with patches of mixed forests and bare soil. Overall, soils are poor and thin. Droughts occur frequently and agricultural fields are prone to erosion.

Beginning around 1968, the West African Sahel has undergone a thirty-year decline in annual rainfall, termed Sahelian desiccation (Hulme 2001). This dry period has been punctuated by two severe droughts from 1968 to 1972 and from 1983 to 1985 . These regional rainfall trends and droughts are well-represented in the long-term rainfall record for Ouagadougou (Figure 4). This is also true for the shorter meteorological record available for Kongoussi and other stations (West et al. 2008). There has been some recent improvement in precipitation and there is great scientific interest regarding Sahelian rainfall recovery and the "greening" of the Sahel (Herrmann et al. 2005; Barbier et al. 2009). At the time of fieldwork in 2004, however, people consistently expressed their belief that they were in a long-term drought (West 2010).

Despite these challenging climatic conditions, the population density on the northern Central Plateau is high (over 100 people $/ \mathrm{km}^{2}$ in some areas) and has been so since the period of French colonization around 1900. This is due in large part to the presence of several centralized Mossi kingdoms on the Central Plateau, which attracted surrounding peoples who sought their military protection from other regional powers (Izard 1985; Lahuec 1980; Marchal 1983). The Mossi remain the most numerous ethnic group and the Central Plateau is the Mossi heartland.

\section{Livelihood diversification}

Like other parts of sub-Saharan Africa and other parts of the world, Mossi households are actively engaged in processes of livelihood diversification. Early ethnographic works describe them as primarily farmers (Hammond 1966; Izard 1985; Izard-Héritier and Izard 1959; Skinner 1964). Mossi practice rainfed subsistence agriculture using mostly hand hoes, although wealthier households utilize animal traction. But, they have always engaged in other economic activities outside of agriculture. Mossi have historically migrated to cocoa plantations in southern parts of neighboring Côte d'Ivoire or Ghana and these patterns are rooted in deeper pre-colonial regional trade systems (Cordell et al. 1996). Mossi migration is mostly circular where individuals leave their natal region, work in Côte d'Ivoire or further afield for several years or decades, and then return to their home village. In terms of internal migration within Burkina Faso, Mossi have also 
permanently moved to urban areas and regions of southern or southwestern Burkina but maintain strong connections to home villages (Gray 2003; McMillan 1995; Wouterse and Taylor 2008). Gold mining opportunities have also drawn migrants (Côte 2013).

Mossi have also progressively incorporated more livestock into their farming systems. Traditionally, there was a competitive and symbiotic relationship between Mossi farmers and Fulani (Fulbe) pastoralists in the northern Central Plateau (Breusers et al. 1998). Mossi households used to entrust their cattle to Fulani herders but have gradually developed the ability to manage, graze, and stall-feed their herds independently. Road construction has improved access to urban and southern livestock markets, which have encouraged Mossi to invest in larger herds. During the droughts of the 1970s and 1980s, pastoral groups to the north were forced to liquidate their herds and wealthy Mossi households took advantage of these opportunities to expand their cattle holdings (Turner et al. 2011). Many households on the northern Central Plateau consider themselves full-fledged agro-pastoralists and integrate animal husbandry with agriculture.

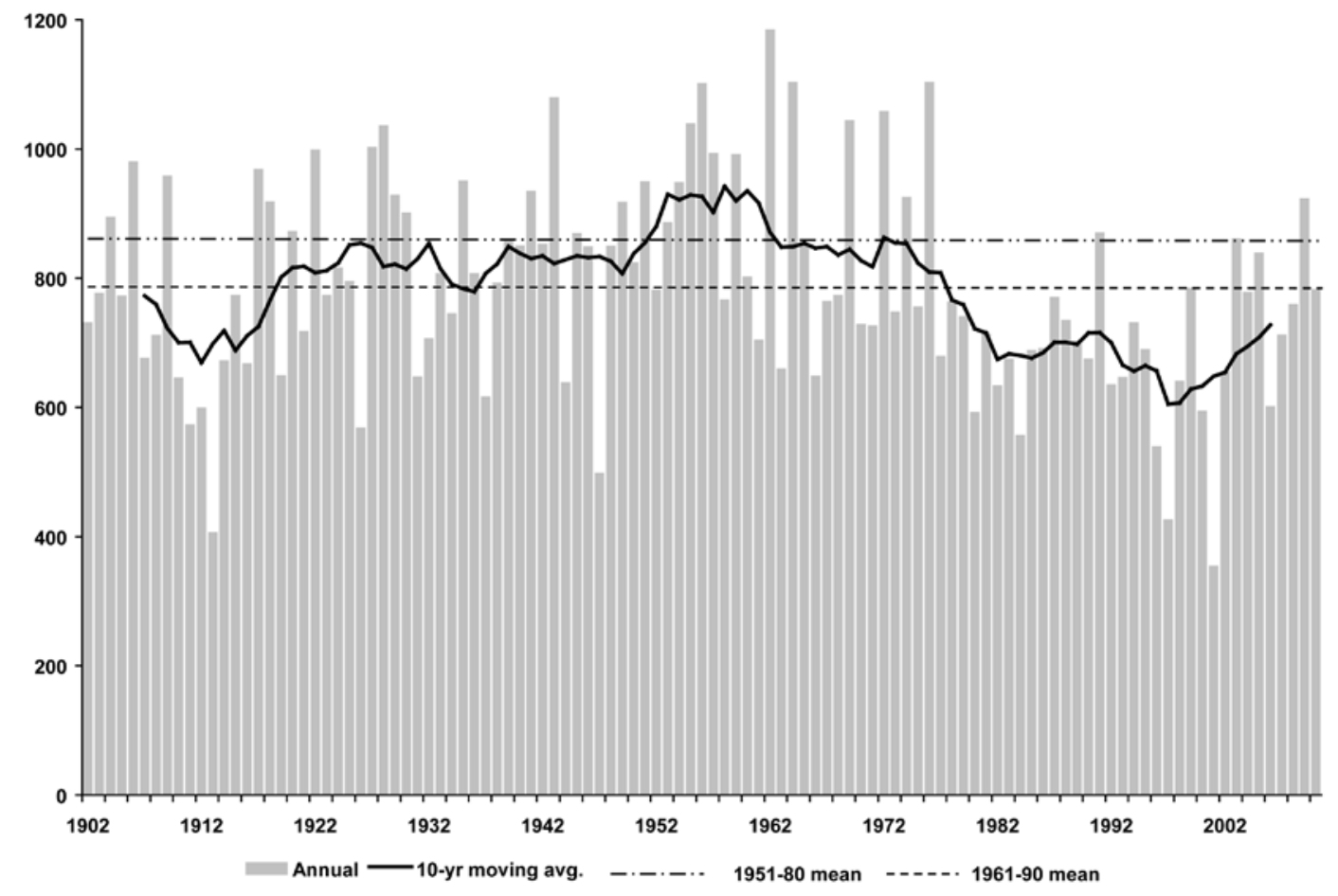

Figure 4: Annual precipitation for Ouagadougou, Burkina Faso, 1902 to 2010 (y axis: mm). Source: precipitation from NOAA NCDC GHCN v2beta: Monthly weather station precipitation data from the Global Historical Climate Network (see Vose et al. 1992).

The most hazardous - as well as most lucrative - off farm economic activity is artisanal gold-mining. The geology of Burkina Faso has extensive and rich gold-bearing mineral deposits, which have been exploited on a small-scale for centuries. There are many scattered gold camps in the northern Central Plateau and Mossi actively work in artisanal gold-mining crews. These artisanal mines began in the 1980s as a response to the Sahelian Drought (Werthmann 2003). Shafts often collapse, people use mercury for amalgamation, and gold camps have little access to clean water, latrines, or other health services. Prostitution, drugs, and alcohol are prevalent features of gold camps. Despite these risks, people can work in the gold camps during the dry season and return to their farms during the wet season for the agricultural campaign (Côte 2013). Some Mossi have made substantial fortunes through gold-mining and it is an important form of livelihood diversification - especially when migration to Côte d'Ivoire was halted during that country's civil war (2002-2007).

Taken altogether, Mossi households have diversified their livelihoods into sectors that are less affected by droughts and rainfall variability associated with desiccation. Rain-fed subsistence agriculture remains the primary economic activity but this is supplemented by numerous others described above. Offfarm opportunities allow Mossi to purchase grain when rains fail and to progressively accumulate assets once 
these needs are met (see Figure 1). Livelihood diversification has decreased the sensitivity and increased the resilience of Mossi households to drought.

\section{Soil and water conservation (SWC) projects}

As a response to droughts in the 1970s and 1980s, the Burkinabé Government partnered with international NGOs and bilateral agencies to help rural producers on the northern Central Plateau rehabilitate agricultural fields. Mossi farmers have been experimenting with indigenous techniques to improve soil fertility and adapt to decreased rainfall. In neighboring Yatenga province, people had been experimenting with traditional planting pits, or zaï, which are shallow holes farmers dig in the dry season (Reij et al. 2005). They leave a low berm and then place a small amount of compost in the pit. As the rains commence, farmers plant seed in zaï and cereal crops can withstand dry periods due to the retention of moisture in the pocket. Preparing zaï is very labor intensive since holes are difficult to dig in the crusted soils during the dry season. So, they can only be implemented on a small scale. The OXFAM-funded Agroforestry Project in Yatenga experimented with contour stone bunds or diguettes in 1979 (Atampugre 1993). These lines of stone were constructed by aligning low rock walls along the contour of agricultural fields to improve rainfall percolation and to slow erosion. Around the same time in Bam Province, a French volunteer in the village of Rissiam (5 km west of Kongoussi and very near Sakou) helped villagers experiment with other soil conservation techniques (Reij et al. 2005). Rissiam began constructing level permeable rock dams across gullies to prevent their spread and slow erosion.

All of these experimental techniques produced promising results. They also demonstrated that appropriate technologies based on local knowledge using locally available materials could help farmers adapt to decreased rainfall associated with Sahelian desiccation (West et al. 2008). Overall, over 100,000 ha in the region have been rehabilitated with contour stone bunds since the mid-1980s (Reij et al. 2005: 649). Countless more have been improved with other SWC techniques. NGOs, international agencies and the Burkinabé Government provided technical assistance and transportation but village organizations provided all the labor. People were not paid to participate in SWC projects and few additional incentives were provided (i.e., food for work). Almost all work was volunteered because farmers recognized the need to conserve soils and saw how effective these new techniques were. Diguettes, zaï, and level permeable rock dams are now prominent features of the landscape throughout the northern Central Plateau.

Several works have documented the impacts of SWC projects on the northern Central Plateau (Atampugre 1993; Reij and Thiombiano 2003; Reij et al. 2005; Batterbury 1998; Batterbury and Forsyth 1999; Batterbury 1996). Although noting the achievements of soil and water conservation projects, researchers have also pointed out that they do not benefit all segments of a community, remain dependent on donor financial support, and rely mostly on the labor of women who do not directly benefit from SWC improvements (Batterbury 1998; Atampugre 1993).

Reij, Tappan, and Belemvire systematically compared nine villages with significant SWC investments and three without (Reij et al. 2005; Reij and Thiombiano 2003). Results in communities with SWC projects were spectacular. Average yields in villages with SWC measured $793 \mathrm{~kg} / \mathrm{ha}$ compared to $611 \mathrm{~kg} / \mathrm{ha}$ in those without (Reij et al. 2005: 651). Fields with SWC improvements also have a greater numbers of trees. In part this is because farmers provided additional protection to trees in their fields and part is due to natural regeneration as soils stabilized and erosion slowed. Although not definitively measured, villages also experienced substantial increases of up to 5 meters in groundwater levels (Reij et al. 2005: 652). SWC improvements helped farmers intensify their agricultural production. As food security improved and erosion decreased, farmers invested in cattle and other livestock, which in turn led them to produce greater amounts of compost by stall-feeding their animals. As SWC improvements prevent the organic matter from washing away, farmers became more motivated to raise animals, produce compost and enrich their fields. Goldmining and migration remittances have also provided cash for investing in animals and intensifying agriculture.

Overall, the introduction of SWC technologies assisted Mossi farmers in becoming less sensitive and more resilient to droughts despite ongoing desiccation. Reij et al. acknowledge that although their household data were weak, they do show that these projects have engendered a "process of accumulation or asset building" (2005: 652). This study addresses this weakness and adds greater quantitative detail by comparing previous records of Mossi household assets with those currently held by contemporary households in three villages. I specifically assess the degree to which asset accumulation has taken place for poor, medium and wealthy households.

\section{Previous studies of Mossi households}

Several extensive studies of Mossi villages took place in the 1970s and 1980s by French researchers associated with the "terroir school" of geography (Bassett et al. 2007). These geographers sought to understand how villages managed their natural resources as collective groups. Their work was very influential and contributed to later development projects based on this model of village-level organization especially the gestion des terroirs villagois (GTV, or village land use management) approach, which is very 
prominent in Burkina Faso (Batterbury 1998). These reports feature comprehensive data on village soils, land use, crops, and other aspects of rural agricultural production for selected villages on the Central Plateau (Imbs 1987; Kohler 1971; Lahuec 1980; Marchal 1983). Two in particular provide limited data on Mossi household structure from the village of Kumtaabo (Imbs 1987) and Dakola (Kohler 1971) in Yatenga Province. Kumtaabo was surveyed by Françoise Imbs between 1969 and 1973. Dakola was surveyed by Jean Marie Kohler between 1965 and 1968. The villages are located in agro-climatic zones similar to Kongoussi and their data provides a baseline on household structure that can be compared with the data presented here. Table 1 summarizes the study characteristics used for comparison.

The International Food Policy Research Institute (IFPRI) and the International Crops Research Institute for the Semi-arid Tropics (ICRISAT) conducted household-level surveys in 1984-1985 (Reardon and Matlon 1989; Reardon and Matlon 1988; Reardon and Taylor 1996). This study took place during the massive Sahelian drought of 1983-1985 and compared household food security between communities in the Sahelian and Sudano-Sahelian zones of northern Burkina Faso. The researchers surveyed four villages. Two were Mossi villages in Yatenga Province and two were mostly Fulani communities around Djibo, lying 100 $\mathrm{km}$ north-east of the study area. Their survey instrument contained questions regarding household demographics, livestock wealth, consumption and agricultural production. The researchers reported most extensively on one Mossi village, Kolbila, located near the town of Yako in Passoré Province. Kolbila lies west of the study area featured in this article but agro-climatic, soil, and ethnic conditions are similar. Thus, household data from this village collected 20 years earlier can serve as a reasonable baseline for comparison with the data presented here.

\begin{tabular}{|c|c|c|c|c|}
\hline \multirow[b]{2}{*}{ Village, Province } & \multirow{2}{*}{$\begin{array}{l}\text { Year of } \\
\text { fieldwork }\end{array}$} & \multirow[b]{2}{*}{ Source } & \multicolumn{2}{|c|}{ Capital type and indicator used for comparison } \\
\hline & & & Type & Indicator \\
\hline Dakola, Yatenga & $1965-68$ & Kohler, 1971 & Human & $\begin{array}{l}\text { Percentage of nuclear and extended } \\
\text { households }\end{array}$ \\
\hline Kumtaabo, Yatenga & 1969-73 & Imbs, 1987 & Human & $\begin{array}{l}\text { Percentage of nuclear and extended } \\
\text { households }\end{array}$ \\
\hline \multirow[t]{2}{*}{ Kolbila, Yatenga } & \multirow[t]{2}{*}{ 1983-85 } & \multirow[t]{2}{*}{$\begin{array}{l}\text { Reardon and } \\
\text { Matlon, } 1989\end{array}$} & Financial & $\begin{array}{l}\text { Mean livestock wealth by household wealth } \\
\text { category }\end{array}$ \\
\hline & & & Natural & $\begin{array}{l}\text { Percentage of households meeting } \\
\text { production sufficiency }\end{array}$ \\
\hline $\begin{array}{l}12 \text { villages in Bam, } \\
\text { Yatenga, and } \\
\text { Sanmatenga }\end{array}$ & 2002 & $\begin{array}{l}\text { Reij et al., 2005; } \\
\text { Reij and Thiombano, } \\
2003\end{array}$ & Natural & $\begin{array}{l}\text { Percentage of households with SWC } \\
\text { improvements }\end{array}$ \\
\hline
\end{tabular}

Table 1: Previous studies used as baselines for comparison

\section{Kongoussi}

The Department of Kongoussi is part of the larger Province of Bam (Figure 5). Its provincial capital is the town of Kongoussi, which is a relatively large urban area of 25,000 people. Many governmental offices are located in the town as well as numerous NGOs. It is connected to the capital city Ouagadougou to the south and other large urban areas to the east and west by improved dirt roads that are passable even in the rainy season. ${ }^{2}$ Thus, the market is quite large and the town hosts many shops and merchants. Numerous households in villages throughout the department have at least one member who is formally or informally employed in Kongoussi. As a regional transportation hub, Kongoussi facilitates the flow of livestock from the surrounding area to Ouagadougou and neighboring Côte d'Ivoire. Conversely, the town facilitates the flow of grain from wetter regions in the south to the drought-prone north. The province owes its name to Lake Bam, which is the largest natural lake in the country. Bam Province, like its neighbors on the northern Central Plateau suffers chronic seasonal famine. The Famine Early Warning System (FEWS) for Burkina Faso often lists Bam as one of several provinces of the Central Plateau facing food insecurity. Kongoussi was also home for the Burkinabé government project PATECORE, funded by the German Ministry of Cooperation (GTZ, now GIZ). PATECORE was the primary organization providing technical assistance for SWC projects in Bam from 1988 to 2005.

\footnotetext{
${ }^{2}$ The road to the capital has been subsequently been paved.
} 


\section{Survey villages}

Fieldwork took place in three villages: Loulouka, Sakou, and Kouka. These villages were selected because they offer different opportunities for livelihood diversification. Their general characteristics are summarized in Table 2.

\begin{tabular}{|c|c|c|c|c|}
\hline Village & Mossi sub-groups & $\begin{array}{l}\text { Access to } \\
\text { markets }\end{array}$ & $\begin{array}{l}\text { SWC } \\
\text { improvements }\end{array}$ & Livelihood diversification and types \\
\hline Loulouka & $\begin{array}{l}\text { Saaba (forgeron) or } \\
\text { metalsmiths }\end{array}$ & High & Very high & $\begin{array}{l}\text { High - agro-pastoralism, gardening, } \\
\text { fishing, urban employment, artisanal } \\
\text { gold-mining, migration }\end{array}$ \\
\hline Sakou & $\begin{array}{l}\text { Nyonosé, Yarsé, Saaba, } \\
\text { Nakomsé }\end{array}$ & Moderate & High & $\begin{array}{l}\text { Medium - agro-pastoralism, market } \\
\text { commerce, migration }\end{array}$ \\
\hline Kouka & $\begin{array}{l}\text { Nakombsé, Nyonosé, } \\
\text { Saaba, Yarsé, Silmi- } \\
\text { Moose }\end{array}$ & Low & Low & $\begin{array}{l}\text { Low - agro-pastoralism, artisanal } \\
\text { gold-mining, urban commerce, } \\
\text { migration }\end{array}$ \\
\hline
\end{tabular}

Table 2: Village characteristics.

Loulouka lies $2 \mathrm{~km}$ north of Kongoussi next to Lake Bam. Its residents have access to dry-season gardening and fishing. Households typically have at least one member who works in Kongoussi but they also maintain farms. Due to its proximity to an urban area, households have less available land for pasture but ready access to livestock markets and transportation. This also means they have less agricultural land and the village has a high population density. Animals are mostly stall-fed with crop residues. Many households integrate farming with animal-raising and have become full-fledged agro-pastoralists. Even though mining camps are far away, Loulouka participates heavily in gold-mining. Rock is readily available in nearby hills and trucks for transporting are based in Kongoussi. Thus, Loulouka has extensive SWC improvements and high livelihood diversification.

Sakou lies 15 km west of Kongoussi just off a main improved dirt road. Every three days, Sakou hosts a large market that provides goods and services to surrounding villages. The market provides limited informal employment only on market days and a few boutiques sell consumer goods. There is no lake or reservoir and households cannot garden except by traveling long distances. Households have good access to pastures and to livestock markets. Agro-pastoralism is also high in Sakou but fewer households engage in artisanal gold-mining. This is due perhaps to more stable opportunities for informal employment associated with the market. The population density is medium. Rock and transportation for diguette construction are relatively easily accessible. Sakou also hosts several dynamic SWC groupements, or village organizations, with very capable leaders. Investments in SWC are high in Sakou and livelihood diversification is moderate.

Kouka lies $20 \mathrm{~km}$ north of Kongoussi on un-improved dirt roads that are impassable by vehicle in the rainy season. It is the most remote of the three villages. The village is located next to a shallow lowland area that floods during the rainy season. People are able to take advantage of these floodwaters to sow sorghum late into the rainy season. Kouka generally has better soils and better growing conditions than the other two villages. Kouka has ample brousse, or non-agricultural bush, for pasture but residents have trouble transporting livestock to markets. There is almost no formal employment in Kouka except for jobs associated with the primary school. The population density is low. Sources of rock for SWC projects lie several kilometers away and it is very difficult for trucks from Kongoussi to transport rock to the village. The low population density and relatively good soils also decrease the need for SWC improvements. Thus, Kouka has less extensive SWC improvements than the other two villages and opportunities to diversify are low.

\section{Methods}

Fieldwork was conducted over a twelve-month period in 2004. I have conducted additional fieldwork in Kongoussi for brief two-week periods in 2010, 2011, and 2012. Working with a research assistant in 2004, we collected data on household characteristics in Loulouka, Kouka, and Sakou. ${ }^{3}$ We randomly selected households from village census lists and stratified the sample by wealth, food-security, and Mossi sub-group. Overall, 97 households participated in the survey with approximately 32 households per village. Households

\footnotetext{
${ }^{3}$ Aimé Somé was my research assistant who helped with translation, protocol, and logistics. This research would not have been possible without his assistance. I refer to 'we' when discussing fieldwork Somé and I conducted together but use 'I' when discussing analyses I conducted by myself.
} 
were defined as economic as opposed to demographic or residential units (West 2010). Thus, a household consists of all members who work together in a field, pool resources, share meals, and recognize the authority of single head. This definition is consistent with those used by other authors and enables comparison. The survey instrument contained questions regarding household demographics, investment in SWC, livestock numbers, and grain production for each of the last five years (1999 to 2003) based on recall.

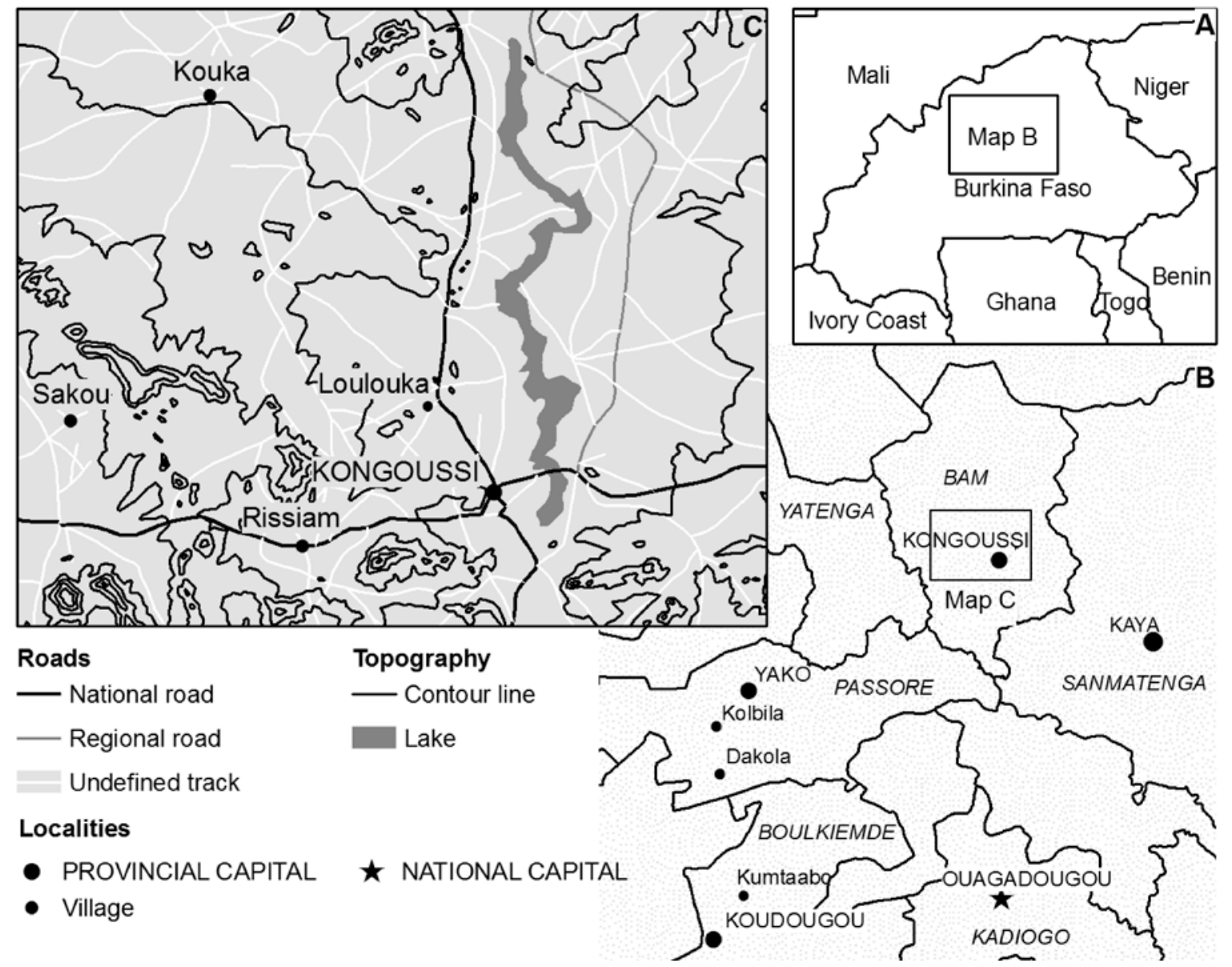

Figure 5: Maps. Map A is Burkina Faso; Map B is the Northern Central Plateau; Map C is the study area.

During the survey, we also informally interviewed participants. As they responded to different sections, we would ask them to explain their responses. These explanations were recorded into a notebook and then transcribed. We also participated in daily social activities such as visiting local dolo (sorghum beer) stands, shopping at local marchés, or markets, talking meals with local families, attending ceremonies, and informally visiting people while they worked in their fields. I kept a daily digital journal of these participant observations. I also formally interviewed local NGO staff, extension agents, forestry officials, and other people with expert knowledge regarding SWC in the region. The analysis below draws on these qualitative data to elucidate certain points.

Using SPSS, the survey data was processed in order to make household-level information comparable with other studies. Households were classified as extended or nuclear based on criteria used by Kohler (1971) and Imbs (1987). I converted the total livestock wealth to monetary equivalents in West African CFA francs (CFA) based on market prices. I also converted the total millet and sorghum harvest of 2003 into CFA, based 
on producer prices for cereals in November and December of $2004{ }^{4}$ Taking the sum of these two variables and dividing by the number of Adult Equivalents (AE), I calculated the total wealth per capita for each household. Then, I created terciles based on this variable and classified each household into one wealth category: poor, medium, and rich. These wealth categories are similar to those used by Reardon and Matlon (1989:123) and enable comparison with their 1984-1985 Kolbila data.

\section{Results}

I used the survey data in order to compare contemporary household assets with those of previous studies across the three villages. For certain characteristics, I made additional comparisons across the three wealth categories within each village in order to be consistent with the Kolbila study.

\section{Natural capital}

In previous studies by Reij and colleagues (Reij et al. 2005; Reij and Thiombiano 2003), researchers had documented the beneficial effects of SWC improvements on crop yields. Farmers with whom we worked always spoke positively about their diguettes but our survey was unable to quantify their impacts for each household - i.e., yield in fields with or without SWC. I calculated the percentage of households in each village who had diguettes or other SWC improvements in their fields in order to evaluate the extent to which households had benefited from SWC programs.

As an indicator of increased natural capital, nearly all households across the three villages had SWC improvements in their fields (Figure 6). Only eight of 95 households did not. These were mostly households whose patrilineages had settled more recently in the village. As newcomers, they have less access to land and weaker rights to farmland. During informal visits to farmer fields, we witnessed extensive networks of diguettes or semi-permeable dikes throughout village landscapes with the notable exception of Kouka. Residents of Kouka explained that sources for rock lie far away and that it is difficult to transport them to village fields. Representatives of NGOs still engaged in SWC explained that while this is true, the community of Kouka has also recently split to form another village called Rambo. Land tenure disputes between the two villages prevent SWC construction. Nonetheless, nearly all households across the three villages have had at least some improvement in their natural capital due to the presence of diguettes, zaï, or semi-permeable dikes in their fields. There are intra- and inter-household differences in the adoption of SWC measures but this is beyond the scope of the study presented here.

A fundamental goal of SWC projects is to increase crop yields by making more moisture available and retaining organic matter. In fact, one wealthy farmer in Loulouka told us he had extensive SWC investments throughout all of his fields. He explained how important they are and added;

You have to understand that these diguettes are not for me. They are for my children and my grandchildren. Even when I die, due to these diguettes PATECORE helped me construct, my children will always have food. They will never know hunger like I have. (HH 156, Loulouka, 8/13/2004)

Thus, investments in SWC have a positive and lasting effect on household food security.

I sought to document the degree to which food security had improved by measuring household production sufficiency. Reardon and Matlon defined production sufficiency as the ability of a household to meet at least $80 \%$ of a $2,280 \mathrm{kcal} / \mathrm{AE} /$ day dietary requirement through their own production of grain, pulses, and nuts (1989: 124-125). Such detailed measurements were not possible with our household survey. But, we used similar production sufficiency criteria used by the Famine Early Warning System of Burkina Faso (FEWS) based on grain requirements of $190 \mathrm{~kg} / \mathrm{AE} /$ year (FEWSNET 2001: 3).

I calculated the percentage of households within each wealth category for each village that produced at least $190 \mathrm{~kg} / \mathrm{AE}$ in 2003. By all accounts, participants stated that precipitation in this year was high and the seasonal distribution of rainfall was ideal (see Figure 4). The PATECORE meteorological station in Pouni next to Kongoussi measured $749 \mathrm{~mm}$ of precipitation, which is 25\% above the 1971-2000 mean of $615 \mathrm{~mm}$. There were 41 days of rainfall between May and September with no prolonged dry periods (i.e., more than ten days with no rain). Older participants stated that the rainy season reminded them of how rains used to be in the decades preceding desiccation. Many households reported record harvests and some granaries were literally overflowing with millet and sorghum. Thus, 2003 is a model year for assessing production sufficiency since harvests should have been high across all households.

Reardon and Matlon (1989: 124) reported low percentages of production sufficiency for poor Kolbila households and high percentages for rich households. This was during some of the worst Sahelian drought

\footnotetext{
${ }^{4}$ Based on data from the Société de Gestion du Stock de Sécurité Alimentaire (SONAGESS) of Burkina Faso for the town of Ziniaré to the south of Kongoussi. The average producer price for millet and white sorghum was $112 \mathrm{CFA} / \mathrm{kg}$. (CFA or Communauté Financière Africaine Francs; US\$ 1= 500 CFA in June, 2004).
} 
years (1983-1984) and their results should reflect a year of very poor agricultural performance. Nonetheless, the Kongoussi data show similar results (Figure 7). In Loulouka and Sakou, poor households tend not to be production sufficient while rich households are. There is some improvement in food security for poor households in Kouka, however. Because of Kouka's proximity to a bas-fond (low-lying area that floods seasonally), soils are relatively rich and crop yields are high. Interestingly, medium and rich households in Kouka tend not to be production sufficient. Members of these categories in Kouka are Yarsé and Silmi-Moose agro-pastoralists and are able to purchase grain through the sale of their animals. Overall, the Kongoussi case indicates that there has been little improvement in food security over the last twenty years especially because the Kolbila data represent years of extreme drought and the Kongoussi data an exceptionally good year in terms of rain.

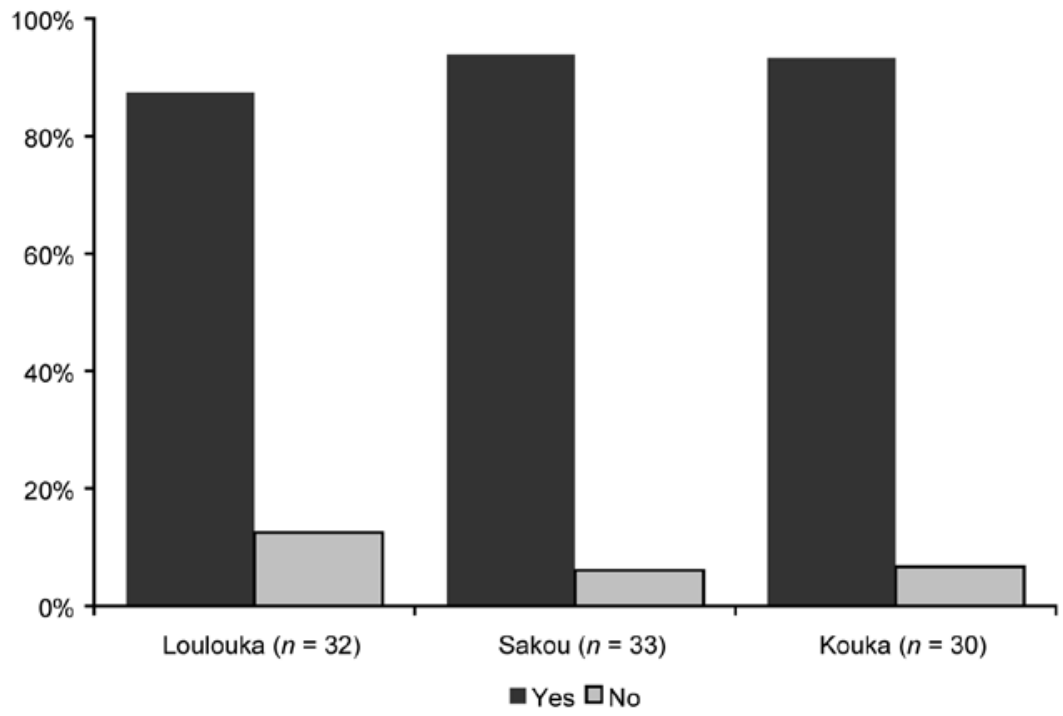

Figure 6: Percentage of households with SWC improvements, 2004.

Why do poor and medium households remain food insecure despite SWC investments and improved rainfall? Some participants explained that, indeed, rainfall was high in 2003 but that this had negative consequences for households in Loulouka in Kouka whose fields lie along the lake or in the bas-fond area. Their fields flooded at the end of the rainy season, which meant they could not harvest their crops. Researchers have suggested that Sahelian desiccation has resulted in increased interannual rainfall variability making the region more prone to both droughts and floods (Tschakert et al. 2010). Mossi farmers offset these risks by establishing scattered fields in both upland and lowland areas, assuming they can obtain land (Batterbury 1996; Roncoli et al. 2001).

One Mossi vieux, or elder, discussed the interaction of desiccation with sorghum and millet landraces;

The rains changed around 1970. The sécheresse (drought) started then. When I was eleven, we would plant a certain variety of millet in August and harvest it in December. We would plant older varieties of millet and sorghum. There were 50-day varieties, 70-day varieties, 120-day varieties. No one plants these anymore and all the millet and sorghum are short-cycle varieties. (HH 02, Pouni, 8/1/2004)

Long-cycle sorghum and millet varieties (i.e., 120-day) could have potentially withstood the flooding that occurred in 2003, but they have disappeared from the region and farmers' grain repertoires (see Ingram et al. 2002). Some farmers similarly stated they now "expect the rainy season to be cut" (anticipate extended dry spells during the rainy season); put less effort into their upland fields, and subsequently rely more heavily on their lowland fields.

Several participants explained that harvests were poor because they "lack their bras valides." These are able-bodied young males that provide the necessary labor for preparing and weeding fields. In many cases, these sons, brothers, and uncles are missing because they have migrated to urban areas, Burkina's cotton zones, local gold fields, or plantations in Côte d'Ivoire. In the study period, the civil war in Côte d'Ivoire prevented the latter migrants from returning home for the agricultural campaign. Similarly, many of 
these young men dislike working for their older brothers or uncles in communal fields, which "provide only a little bit of food, but no money." They prefer to take their chances, leave the household, and work year-round mining for gold. Some reported earning over 400,000 CFA ( US\$ 800) in a single year.

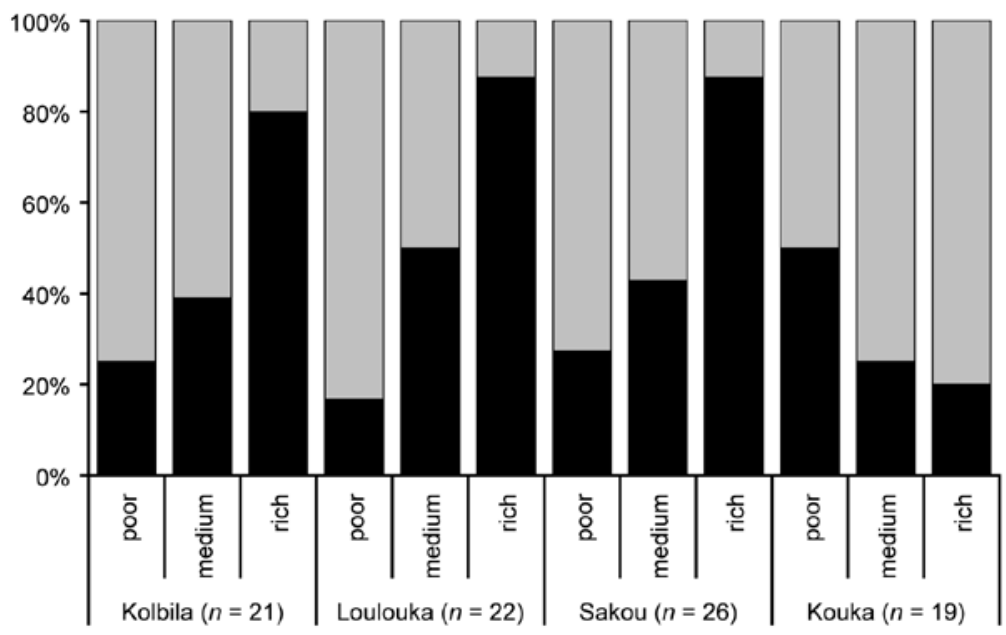

- Yes $\square$ No

Figure 7: Percentage of households meeting production sufficiency, 2004.

Lastly, soil fertility is directly linked to animal ownership. Population densities throughout the northern Central Plateau no longer allow fields to left fallow long enough to recover and most are now used continuously every year (Broekhuyse and Allen 1988; Marchal 1983). Fertilizer is expensive and few farmers can purchase it in the quantities necessary. As a local extension agent explained;

We do not advise rural producers to use fertilizer. Instead, we encourage them to produce more manure. The soils here need their entire structure altered. Without more organic matter, the fertilizer they use is not retained. Also, they risk burning the young plants. Some farmers only have the means to buy small amounts of fertilizer and they actually sow it with their seeds. This is particularly dangerous because it will burn the young plants. (01, Kongoussi, 8/1/2004).

Without long fallows, fields have to be improved with manure. Poor households have few or no animals and face difficulties producing it in large quantities. They can, however, invite others to browse their herds in fields following the harvest to remove stubble. Over many seasons, this can slowly alter the soil structure and improve fertility. Likewise, farmers can prepare zaï pockets, add small amounts of compost to them, and incrementally restore degraded fields. This extension agent added that "this depends on a person's willingness to work hard and invest in their fields." Some people are not willing to do so and suffer chronic food insecurity. Diguettes alone are not enough to restore soil fertility on the densely-populated and degraded northern Central Plateau.

\section{Financial capital}

The survey sought to detect improvements in financial capital among Kongoussi households. By increasing yields and improving food security, SWC projects sought to assist in reducing poverty (Reij and Thiombiano 2003). Mossi invest cash earnings in animal wealth. By purchasing young goats, sheep, or even cattle, they can raise these animals and develop herds. Mature livestock can be sold in order to purchase grain or pay for other household needs. As households become less vulnerable to crop losses, they can invest more in animals. Thus, livestock are a form of financial capital. We asked household heads to enumerate the number of goats, sheep, and cattle the household collectively owned. These figures were converted to monetary equivalents (CFA or Communauté Financière Africaine Francs; US\$ 1= 500 CFA) based on market prices provided in FEWS reports. The total animal wealth was summed for each household and then divided by the number of adult equivalents to calculate per capita animal wealth (Table 3). This procedure is again similar to that used by Reardon and Matlon (1989). Table 3 compares contemporary results in Kongoussi with those of Kolbila. 


\begin{tabular}{llcccc}
\hline & & \multicolumn{2}{c}{ Mean livestock monetary wealth (CFA/AE) } & \\
& Village $(n)$ & Poor & Middle & Rich & All Categories \\
\hline $1984-5^{*}$ & Kolbila (21) & 16,117 & 25,633 & 36,065 & 24,892 \\
\multirow{2}{*}{$2004^{\dagger}$} & & & & & \\
& Loulouka (26) & 8,759 & 33,163 & 81,220 & 45,286 \\
& Sakou (32) & 9,260 & 36,561 & 101,693 & 44,641 \\
& Kouka (23) & 12,061 & 36,732 & 111,787 & 50,994 \\
\hline
\end{tabular}

* Source: Reardon and Matlon 1989:124

† Source: Author's fieldwork

\# Animal wealth was adjusted for inflation and indexed to the year 2000. AE= Adult equivalents.

Table 3: Livestock monetary wealth by category and village.

The results point out that financial capital among Mossi households is mixed. Poor households across all three contemporary Kongoussi villages have about one-half the animal wealth of Kolbila households 20 years ago. There was modest improvement among medium households while animal wealth doubled or tripled among contemporary rich households. The process of asset accumulation has been most pronounced for rich households. Poor households remain poor. Moreover, the wealthiest households reside in Kouka, which is a village with minimal SWC investments (see Table 2).

These results are partially explained by macro-economic policies. As part of larger structural adjustment programs, the value of the CFA was reduced by 50 per cent in 1994. One French franc became worth 100 CFA instead of $50 .^{5}$ Devaluation of the CFA franc essentially made imports into Burkina Faso twice as expensive but actually increased the value (and cost) of locally produced goods including cereals and animals. This has made animals more valuable and also more expensive, which has prevented poorer people from acquiring livestock and developing herds.

Young people particularly emphasized the challenges they face in acquiring animals and integrating them into their farms. Some reported that they initially invested their earnings from Côte d'Ivoire in a few goats or sheep but soon lost them due to diseases or theft. Several young men told us that they had periodically made large sums of money in the gold fields and immediately purchased cattle in order to store this wealth and start herds. They kept these animals in enclosed stalls and mixed their manure with crop residues that the cattle trampled. Over several years, this organic matter would slowly enrich their fields and improve yields.

Decreased rainfall associated with desiccation has increased the frequency of droughts and also possibly floods. Poor households are very sensitive and not very resilient to these extreme events. Because they have few or no animals, they are unable to enrich their fields and withstand dry spells. The few animals they have are frequently sold off to make up for poor harvests. As an example, we interviewed one elder zaksoba, or household head, in Loulouka whose fields are small and located near the Lac du Bam. His compound was well-kept, tidy and several structures had tin roofs - generally an indication of wealth or modest prosperity. As we spoke with him, though, he reported that he had no cattle, no sheep and no goats. There was an empty stall next to the compound with no sign of manure or other animal wastes. We asked if his household used to have livestock and he replied;

Yes, we used to have lots of animals. But, last year [i.e., 2003] there were floods and the lake overflew its banks affecting our fields. There was not enough grain. In previous years, there were also droughts. The rains were bad. I have now sold all my animals over the past five years in order to buy grain. We have no animals now. Before, I had 30 head of livestock but have nothing now. (HH 168, Loulouka, 8/20/2004)

This situation describes the process of progressive asset divestment as depicted in Figure 1 and we encountered similar stories among other poor households.

Members of wealthy households often experienced the opposite dynamic. They discussed how they are unaffected by droughts because of their diguettes, zaï, animal traction, and manure. In good years like 2003, their intensive farming practices can produce large surpluses that can feed their household for over two or more years. As one of the wealthiest people surveyed explained;

\footnotetext{
${ }^{5}$ The values in Table 3 take the 1994 devaluation of the CFA franc into account.
} 
Last year (i.e., 2003) was very good. I saw that the grain we harvested would be more than enough to last until the next harvest. I do this every year. If I see that the harvest is sufficient, I take some of the grain and go sell it. So, I waited several months until millet and sorghum prices began to rise and then sold several sacks of millet. I used this money to buy two young calves for 60,000 or 70,000 CFA [US\$ 120-140]. After raising them for five years, I can sell the mature animals for 105,000 or 110,000 CFA [US\$210-220]. (HH 190, Kouka, 10/13/2004)

We saw similar behavior among other wealthy households. Because 2003 had been a good year, they were actively buying up surplus millet and sorghum in their own village and throughout the province. Grain prices are lowest immediately following the harvest and this provides them with the opportunity to stock and store grain. One individual had constructed an addition to his house in order to store sacks of sorghum. Another had built a huge granary the size of small house for the excess grain.

One person described how did this every year. Harvests vary across the region and people quickly find out which villages produced surplus crops. They travel to these locations, buy grain at reduced prices, and then store it until the soudure, or hungry period, commences in June, July and August. Sorghum or millet can be sold for twice what they paid. As one of these persons explained;

With these profits, I then buy animals - preferably cattle. I then sell these after a little while for buying more grain when the time is right. I buy calves for 50,000 CFA (US\$ 50) (HH 200, Kouka, 10/15/2004)

So long as a household does not run out of their own grain, they can take advantage of opportunities and engage in the process of asset accumulation depicted in Figure 1.

\section{Human capital}

Constructing diguettes, building semi-permeable dams, and digging zaï are labor-intensive activities. Most SWC activities involve village groupements composed of members from numerous households. They collectively gather rocks in outlying areas, load them into vehicles that transport it to village fields, and then align them across several individual fields. Interviewees explained that these groupements would start with the fields of one household and then progressively extend them to other households within the group over several years. Each household donated their labor knowing that the diguettes would eventually reach their fields. In order to participate, households had to be willing to send members to these communal work groups knowing that it could take several years before they benefited directly. If they did not have the necessary labor force to participate, households could contract with an SWC grouppement and pay for their services, but this can be very expensive. Likewise, fully capitalizing on SWC involves herding animals and transporting manure to fields. Altogether then, soil and water conservation projects have created incentives for households to retain members in order to participate in diguette construction and intensify agriculture. This has placed a premium on the human capital, or solidarity and size, of Mossi households.

The survey sought to measure human capital by identifying Kongoussi households as extended or nuclear (West 2009, 2010). Extended households consist of two or more husband-wife pairs and their offspring (e.g., two or more nuclear families). They also have at least one communal field described below. Nuclear households consist of a single husband-wife pair and their offspring (e.g., one nuclear family) and no communal field. Earlier works by French geographers documented the erosion of solidarity among Mossi households. They detected a trend toward fragmentation whereby Mossi production units were becoming more nuclear and less extended (Imbs 1987; Marchal 1987; Kohler 1971). The works of Kohler (1971) and Imbs (1987) reported the percentages of nuclear and extended households for the villages of Dakola and Kumtaabo in which they conducted fieldwork in the 1960s and 1970s. The process of fragmentation leads to households that are more economically autonomous and share fewer resources such as labor, land, and grain. This undermines communal solidarity which is considered a hallmark of Mossi society (Fiske 1991). Using data on household types reported by Kohler and Imbs, I tested the degree to which fragmentation existed among contemporary Kongoussi communities. Figure 8 shows the percentage of each household type across all villages.

Comparing Kumtaabo and Dakola with contemporary Kongoussi region, the results show that fragmentation was attenuated in contemporary villages. The percentage of extended households ranges from 45 percent in Sakou to 65 percent in Loulouka. Interviewed participants emphasized solidarity and spoke proudly of their ability to maintain communal fields or share grain and labor within an extended kin network. 


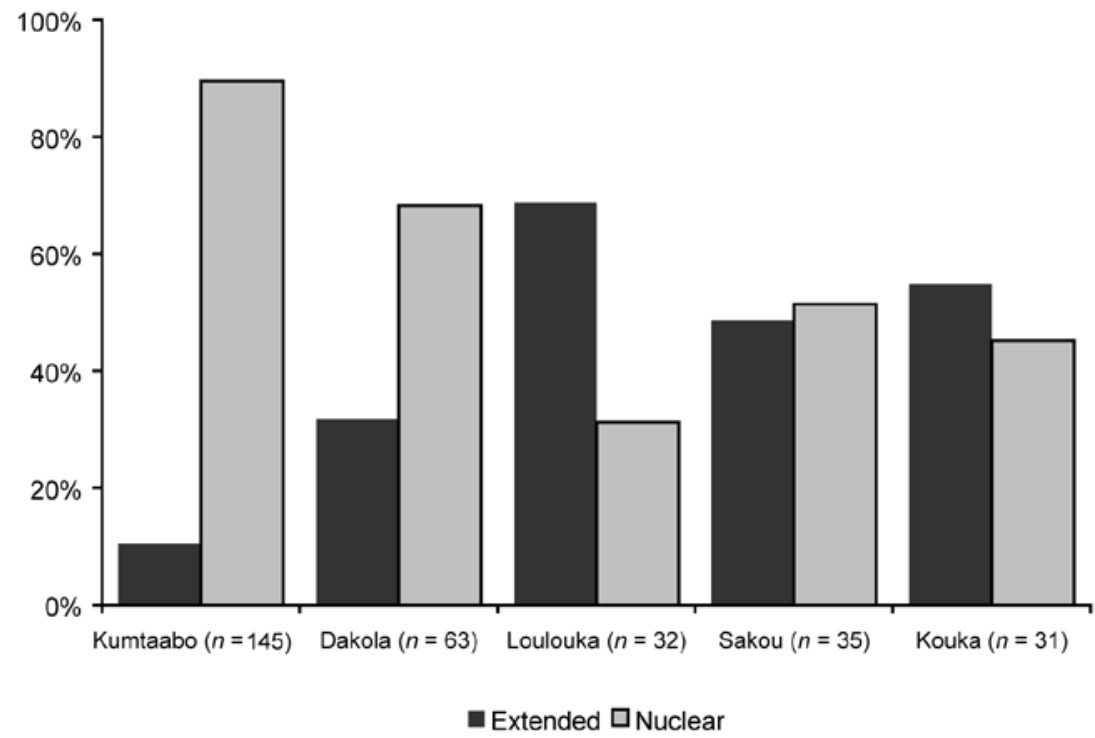

Figure 8: Percentage of household type by village (2004).

A communal field is called a pugkêenga, or "large field" in Mooré (pugkêense - plural). They are associated with large extended households where all members unite during the agricultural season to work collectively. The harvest is held in common for the entire group and managed by the household head (West 2009; West 2010). These pugkêense can also be symbolic fields in which dispersed members of a lineage meet together during the rainy season to reify bonds of solidarity. Most often, however, these fields play an important role in focusing household labor and resources to maximize grain production. As one interviewee told us;

A pugkêenga is very advantageous. You know you will never go hungry because of it. You know that you will eventually have at least some food, even if you don't have any today. This is because people work together and help on another out. (HH 111, Sakou, 6/11/2004).

In particular, they discussed how some members of an extended group can work in the pugkêenga fields while others pursue off-farm work. This is especially important when grain from the previous year's harvest runs out in June, July or August. This is the time that agricultural labor peaks. Being able to split their workforce and send some members to the gold camps while leaving others in the village to tend fields is highly advantageous. Through gold-mining, they can earn just enough money to purchase grain and make it through to the next harvest.

Members of a poor household described the opposite situation. The zaksoba was quite old and ill. He was Yarsé, and members of this Mossi sub-group tend to be relatively wealthy and engaged in commerce. This was not the case for him and his family. He explained that as a member of the village's Yarsé lineage, they are regarded as newcomers and have access to less productive fields with poorer soils. His two sons had left him long ago for Côte d'Ivoire. According to the zaksoba, they were tired of farming, tired of his inability to manage the farm effectively, and especially tired of being hungry all the time. He only has a daughter and two wives who help with their fields although the sons sometimes send a little bit of money. He explained;

My children helped me with my illness. I have become gravely ill and am in chronic pain due to working in the gold mines. Every year, just as I see we will not have enough grain to make it through to the next harvest. So, I take off to the gold mines and work there for a couple days or weeks just so that I make enough money to buy sufficient sorghum and get by. I do this almost every year. I have had many accidents gold-mining and am becoming crippled. I'm becoming too old for working in the gold fields. Since I leave my fields during the rainy season, the others can't keep up with the weeding and tilling. So, we get behind and the harvests are always poor. (HH 119, Sakou, 7/15/2004)

He had no diguettes and lacked the extra household labor to participate in SWC activities. This case exemplifies how small and poor households can become locked in self-perpetuating cycles of grain shortages 
and dependency on off-farm labor. Livelihood diversification is beneficial, but artisanal gold mining can undermine household sustainability.

\section{Conclusion}

Mossi communities on the northern Central Plateau today typify the smallholders Robert Netting described twenty years ago. They rely almost entirely on their own subsistence grain production and also engage in some market transactions in livestock, labor, and gold. The sustainability of these smallholding systems, however, is seriously threatened by droughts, floods, and soil degradation. Nonetheless, Mossi farmers persist on the land and have creatively adapted to these challenges by dramatically altering their environment. They have transformed their landscape and made it more productive through SWC measures. By partnering with the Burkinabé government and international donors, communities have constructed thousands of kilometers of diguettes and dams. These efforts have increased vegetation, slowed erosion, and raised groundwater levels. Mossi have also become less dependent on rainfed agriculture and diversified their livelihood systems. At the level of communities, SWC projects have yielded tangible beneficial results in terms of natural capital.

By using a Sustainable Livelihoods Approach focused livelihood trajectories, however, a different picture emerges. SWC improvements are not associated with positive changes in other livelihood categories. Comparing household-level data from 1984-1985 with recent fieldwork data in 2004 reveals that financial gains have been quite modest. Poor households remain poor. Food security, one aspect of natural capital, has improved somewhat but not for poor households. Social cohesion, an indicator of human capital, on the other hand, has been reinforced and enhanced.

Adding a temporal dimension using quantitative data to SLA assessments allows us to gain insights into processes of change over time. This study has illuminated the dual processes of asset accumulation and divestment for Mossi households. Comparing livelihoods from 2004 with those of Mossi communities 20 to 30 years ago suggests that rich households have been able to engage in a positive cycle of asset accumulation. As they have diversified, these households have been able to take advantage of opportunities to purchase livestock, diversify, and intensify their farming systems. Poor households, on the other hand, have been repeatedly affected by agroclimatic shocks associated with Sahelian desiccation. As crops have failed, they have been forced to sell off animals and divert income from off-farm activities in order to purchase grain. Thus, poor households have been locked in a negative cycle of asset divestment. They remain able to maintain farms and 'get by', but they have become increasingly more sensitive and less resilient to droughts and other shocks such as floods.

SWC projects began on the Central Plateau only twenty-five years ago. It is possible that it will take much more time for the dramatic environmental benefits of these investments to produce concrete social benefits as well. Many community members expressed similar concerns regarding Soil and Water Conservation projects. Villagers explained that some communities had no SWC improvements because they did not realize how beneficial they were until after PATECORE closed its doors. Their SWC operations were halted in 2004-2005 and there has been little additional diguette construction since, except by individuals and small NGOs. Furthermore, some villages had only begun to construct diguettes and realize their potential before operations ceased. They would like to reclaim more land and extend SWC improvements. In informal conversations with regional officials, NGO staff, and village leaders, people frequently emphasized that SWC improvements are only partially realized and that operations should re-commence and expand.

Altogether, SWC projects have engendered a positive trajectory for Mossi livelihood systems on the northern Central Plateau of Burkina Faso over the last two or three decades. These interventions can be considered a qualified development success story for their role in improving the natural capital of households, communities and the entire region. Using a Sustainable Livelihoods Approach, this research has detected that improvements in other forms of capital are more mixed. Rich households have accumulated financial assets and maintained high levels of production sufficiency in cereal grains. Poor households, however, have arguably become even less sustainable over the last twenty years. Their financial assets and food security have decreased over time and their trajectories remain negative. Given the fact that the region has suffered essentially thirty years of drought, the low asset portfolios of poor households are not entirely surprising and there is some room for guarded optimism. Now that Sahelian desiccation may have ended and that there are multiple opportunities to diversify, re-starting and expanding Soil and Water Conservation projects on the northern Central Plateau could be one of the best ways to promote positive livelihood trajectories for all smallholders -- rich and poor alike. 


\section{References}

Atampugre, N. 1993. Behind the lines of stone: the social impact of a soil and water conservation project in the Sahel. Oxford: Oxfam Publications.

Barbier, B., H. Yacouba, H. Karambiri, M. Zoromé and B. Somé. 2009. Human vulnerability to climate variability in the Sahel: farmers' adaptation strategies in northern Burkina Faso. Environmental Management 43(5): 790-803.

Baro, M. 2002. Food insecurity and livelihood systems in Northwest Haiti. Journal of Political Ecology 9: 134.

Bassett, T.J., C. Blanc-Pamard and J. Boutrais. 2007. Constructing locality: the terroir approach in West Africa. Africa 77(1): 104-129.

Batterbury, S.P.J. 1996. Planners or performers? Reflections on indigenous dryland farming in northern Burkina Faso. Agriculture and Human Values 13(3): 12-22.

Batterbury, S.P.J. 1997. The political ecology of environmental management in semi-arid West Africa: case studies from the Central Plateau, Burkina Faso. Ph.D. dissertation. Worcester, MA: Clark University.

Batterbury, S.P.J. 1998. Local environmental management, land degradation and the "Gestion des Terroirs" approach in West Africa: policies and pitfalls. Journal of International Development 10: 871-989.

Batterbury, S.P.J. and T. Forsyth. 1999. Fighting back: human adaptations in marginal environments. Environment 31(6): 6-26.

Bebbington, A.J. 1999. Capitals and capabilities: a framework for analyzing peasant viability, rural livelihoods and poverty. World Development 27(12): 2021-2044.

Bebbington, A.J. 2001. Globalized Andes? Livelihoods, landscapes and development. Ecumene 8(4): 414436. (now Cultural Geographies)

Breusers, M., S. Nederlof and T. Van Rheenen. 1998. Conflict or symbiosis? Disentangling farmer-herdsmen relations: the Mossi and Fulbe of the Central Plateau, Burkina Faso. Journal of Modern African Studies 36(3): 354-380.

Broekhuyse, J.T. and A.M. Allen. 1988. Farming systems research. Human Organization 47(4): 330-342.

Corbett, J. 1988. Famine and household coping strategies. World Development 16(9): 1099-1112.

Cordell, D.D., J.W. Gregory and V. Piché. 1996. Hoe and wage: a social history of a circular migration system in West Africa. Boulder, CO: Westview Press, Inc.

Côte, M. 2013. What's in a right? The liberalisation of gold mining and decentralisation in Burkina Faso. LDPI Working Paper 25. ISS, The Hague: Land Deal Politics Initiative.

Crate, S.A. 2003. Viliui Sakha post-Soviet adaptation: a subarctic test of Netting's smallholder-householder theory. Human Ecology 31(4): 499-528.

Davies, S. 1996. Adaptable livelihoods: coping with food insecurity in the Malian Sahel. New York: St. Martin's Press.

de Haan, L. and A. Zoomers. 2005. Exploring the frontier of livelihoods research. Development and Change 36(1): 27-47.

Ellis, F. 1998. Household strategies and rural livelihood diversification. Journal of Development Studies 35(1): 1-38.

Ellis, F. 2000. Rural livelihoods and diversity in developing countries. Oxford: Oxford University Press.

FEWSNET. 2001 State of food security in Burkina Faso. FEWSNET Update for September-October, 2001 Ouagadougou: USAID Famine Early Warning System Network (http://www.fews.net)

Fiske, A.P. 1991. The structures of social life: the four elementary forms of human relations: communal sharing, authority ranking, equality matching, market pricing. New York: The Free Press. Summary article

Gray, L.C. 2003. Investing in soil fertility: farmer responses to land scarcity in southwestern Burkina Faso. In: Bassett, T. J. and D. Crummey (eds.) African savannas: global narratives and local knowledge of environmental change. Portsmouth, N.H.: Heinemann. Pp72-90.

Hammond, P.B. 1966. Yatenga: technology in the culture of a West African kingdom. New York: The Free Press.

Herrmann, S.M., A. Anyamba and C.J. Tucker. 2005. Recent trends in vegetation dynamics in the African Sahel and their relationship to climate. Global Environmental Change 15(15): 394-404.

Hulme, M. 2001. Climatic perspectives on Sahelian desiccation: 1973-1998. Global Environmental Change 11(1): 19-29.

Imbs, F. 1987. Kumtaabo: une collectivité rurale Mossi et son rapport à l'espace (Burkina Faso). Atlas des Structures Agraires au Sud du Sahara 21. Paris: ORSTOM. 
Ingram, K.T., M.C. Roncoli, and P.H. Kirshen. 2002. Opportunities and constraints for farmers of west Africa to use seasonal precipitation forecasts with Burkina Faso as a case study. Agricultural Systems 74(3): 331-349.

Izard, M. 1985. Gens du pouvoir, gens de la terre. Cambridge: Cambridge University Press.

Izard-Héritier, F. and M. Izard. 1959. Les Mossi du Yatenga: étude de la vie économique et sociale. Bordeaux: Institut des Sciences Humaines Appliqués de l'Université de Bordeaux.

Knutsson, P. 2006. The sustainable livelihoods approach: a framework for knowledge integration assessment. Human Ecology Review 13(1): 90-99.

Kohler, J.M. 1971. Activités agricoles et changements sociaux dans l'Ouest-Mossi (Haute-Volta). Memoires ORSTOM No. 46. Paris: Office de la Recherche Scientifique et Technique Outre-Mer.

Lahuec, J.-P. 1980. Le terroir de Zaongho: les Mossi de Koupéla (Haute-Volta). Atlas des Structures Agraires au Sud du Sahara 15. Paris: ORSTOM.

Marchal, J.-Y. 1983. Yatenga Nord Haute Volta: la dynamique d'un espace rural Soudano-Sahelien. Travaux et Documents de l'ORSTOM 167. Paris: Office de la Recherche Scientifique et Technique Outre-Mer.

Marchal, J.-Y. 1987. En Afrique des savanes, fractionnement des unités d'exploitation rurales ou chacun pour soi. Cahiers ORSTOM Séries des Sciences Humaines 23(3-4): 445-454.

McCabe, J.T. 2003. Toward an anthropological understanding of sustainability. Human Organization 62(2): 91-92.

McMillan, D.E. 1995. Sahel visions: planned settlement and river blindness control in Burkina Faso. Tucson, AZ: University of Arizona Press.

Mortimore, M.J. and W. M. Adams. 1999. Working the Sahel: environment and society in northern Nigeria. New York: Routledge.

Netting, R.M. 1993. Smallholders, householders: farm families and the ecology of intensive, sustainable agriculture. Stanford, CA: Stanford University Press.

Reardon, T. and P. Matlon. 1988. Coping with household-level food insecurity in drought-affected areas of Burkina Faso. World Development 16(9): 1065-1074.

Reardon, T. and P. Matlon. 1989. Seasonal food insecurity and vulnerability in drought-affected regions of Burkina Faso. In: Sahn, D. E. (ed.) Seasonal variability in Third World agriculture: the consequences for food security. Baltimore, MD: The Johns Hopkins University Press. Pp118-136.

Reardon, T. and J.E. Taylor. 1996. Agroclimatic shock, income inequality, and poverty: evidence from Burkina Faso. World Development 24(5): 901-914.

Reij, C., G. Tappan and A. Belemvire. 2005. Changing land management practices and vegetation on the Central Plateau of Burkina Faso (1968-2002). Journal of Arid Environments 63(3): 642-659.

Reij, C. and T. Thiombiano. 2003 Développement rural et environnement au Burkina Faso: la réhabilitation de la capacité productive des terroirs sur la partie nord du Plateau Central entre 1980 et 2001. Rapport de synthèse. Amsterdam: Vrije Universite.

Roncoli, C., K. Ingram and P. Kirshen. 2001. The costs and risks of coping with drought: livelihoood impacts and farmers' responses in Burkina Faso. Climate Research 19(2): 119-132.

Scoones, I. 1998. Sustainable rural livelihoods: a framework for analysis. IDS Working Paper 72. Sussex: Institute for Development Studies.

Scoones, I. 2009. Livelihood perspectives and rural development. The Journal of Peasant Studies 36(1): 171196.

Skinner, E.P. 1964. The Mossi of the Upper Volta: the political development of a Sudanese people. Stanford: Stanford University Press.

Stone, M.P. 2003. Is sustainability for development anthropologists? Human Organization 62(2): 93-99.

Swift, J. 1996. Desertification: narratives, winners and losers. In M. Leach and R. Mearns (eds.) The lie of the land: challenging received wisdom on the African environment. Heinemann: Portsmouth, NH. Pp7390.

Tiffen, M., M.J. Mortimore, and F. Gichuki. 1994. More people, less erosion: environmental recovery in Kenya. Chichester: John Wiley \& Sons.

Tschakert, P., R. Sagoe, G. Ofori-Darko and S.N. Codjoe. 2010. Floods in the Sahel: an analysis of anomalies, memory, and anticipatory learning. Climatic Change 103(3-4): 471-502.

Turner, M.D., A.A. Ayantunde, K.P. Patterson and E.D. Patterson III. 2011. Livelihood transitions and the changing nature of farmer-herder conflict in Sahelian West Africa. Journal of Development Studies 47(2): 183-206.

Valdivia, C. 2005. Andean livelihood strategies and the livestock portfolio. Culture and Agriculture 26(1-2): 69-79. draft 
Vose, R.S., R.L. Schmoyer, P.M. Steurer, T.C. Peterson, R. Heim, T.R. Karl, and J. Eischeid. 1992. The Global Historical Climatology Network: Long-term monthly temperature, precipitation, sea level pressure, and station pressure data. ORNL/CDIAC-53, NDP-041. Oak Ridge National Laboratory, Carbon Dioxide Information Analysis Center.

Werthmann, K. 2003. The president of the gold diggers: sources of power in a gold mine in Burkina Faso. Ethnos 68(1): 95-111.

West, C.T. 2009. Domestic transitions, desiccation, agricultural intensification, and livelihood diversification among rural households on the Central Plateau, Burkina Faso. American Anthropologist 11(3): 275288.

West, C.T. 2010. Household extension and fragmentation: Investigating the socio-environmental dynamics of Mossi domestic transitions. Human Ecology 38(3): 363-376.

West, C.T., C. Roncoli and F. Ouattara. 2008. Local perceptions and regional climate trends on the Central Plateau of Burkina Faso. Land Degradation and Development 19(3): 289-304.

Wouterse, F. and J.E. Taylor. 2008. Migration and income diversification: evidence from Burkina Faso. World Development 36(4): 625-640.

\begin{abstract}
The northern Central Plateau of Burkina Faso has been the site of extensive development assistance since the 1980s. Thousands of hectares of degraded land have been rehabilitated through investments in Soil and Water Conservation (SWC) techniques. Comprehensive assessments of these projects have documented their beneficial impacts. This study extends these insights to consider the effects of SWC on livelihood sustainability by comparing recent household-level indicators with studies conducted twenty years earlier. Comparing quantitative data from two different points in time allows researchers to identify 'livelihood trajectories', or the general direction of either improvement or decline. The results show that although SWC investments have improved the natural capital of Mossi households, improvements in other forms of capital have accrued mostly among wealthy households.
\end{abstract}

Key words: Livelihoods, development, Mossi, Burkina Faso

\title{
Résumé
}

Le Plateau Central nord du Burkina Faso a été le site d'une vaste aide au développement depuis les années 1980. Des milliers d'hectares de terres dégradées ont été réhabilités grâce à des investissements dans les techniques de conservation des sols et de l'eau (CES). Des évaluations complètes de ces projets ont documenté leurs effets bénéfiques. Cette étude élargit ces idées à considérer les effets des CES sur la durabilité des moyens de subsistance en comparant les indicateurs récents au niveau des ménages avec des études menées vingt ans plus tôt. La comparaison des données quantitatives à partir de deux dates différentes permet aux chercheurs d'identifier les «trajectoires de subsistance», ou la direction générale de chaque amélioration ou de déclin. Les résultats montrent que bien que les investissements de CES ont permis d'améliorer le capital naturel des ménages Mossi, des améliorations dans d'autres formes de capital sont constituées principalement chez les ménages riches.

Mots clés: Moyens de subsistance, le développement, Mossi, Burkina Faso

\section{Resumen}

El norte de la meseta central de Burkina Faso ha recibido numerosa asistencia para el desarrollo desde la década de los ochenta. Miles de hectáreas de tierra degradada han sido rehabilitadas a través de inversiones en técnicas de conservación de agua y tierra (SWC, en sus siglas en inglés). Diversas y extensas evaluaciones de estos proyectos han documentado sus beneficiosos impactos. Este estudio extiende estas percepciones para considerar los efectos de SWC sobre la sostenibilidad de subsistencia mediante la comparación de recientes indicadores a nivel doméstico con estudios llevados a cabo veinte años antes. Comparando datos cuantitativos de dos momentos distantes en el tiempo permite a los investigadores identificar 'trayectorias de subsistencia', o la dirección general de mejoras o empeoramientos. Los resultados muestran que aunque las inversiones en SWC han mejorado el capital natural de los hogares en Mossi, las mejoras de otras formas de capital se han concentrado mayoritariamente en hogares adinerados.

Palabras clave: Subsistencia, desarrollo, Mossi, Burkina Faso 